Article

\title{
The Efficacy of Hydrogen Peroxide in Mitigating Cyanobacterial Blooms and Altering Microbial Communities across Four Lakes in NY, USA
}

\author{
Mark W. Lusty and Christopher J. Gobler *i) \\ School of Marine and Atmospheric Sciences, Stony Brook University, Southampton, NY 11968, USA; \\ mark.lusty@stonybrook.edu \\ * Correspondence: christopher.gobler@stonybrook.edu
}

Received: 3 June 2020; Accepted: 22 June 2020; Published: 29 June 2020

check for updates

\begin{abstract}
Hydrogen peroxide $\left(\mathrm{H}_{2} \mathrm{O}_{2}\right)$ has been proposed as an agent to mitigate toxic cyanobacterial blooms due to the heightened sensitivity of cyanobacteria to reactive oxygen species relative to eukaryotic organisms. Here, experiments were conducted using water from four diverse, eutrophic lake ecosystems to study the effects of $\mathrm{H}_{2} \mathrm{O}_{2}$ on cyanobacteria and non-target members of the microbial community. $\mathrm{H}_{2} \mathrm{O}_{2}$ was administered at $4 \mu \mathrm{g} \mathrm{L}^{-1}$ and a combination of fluorometry, microscopy, flow cytometry, and high throughput DNA sequencing were used to quantify the effects on eukaryotic and prokaryotic plankton communities. The addition of $\mathrm{H}_{2} \mathrm{O}_{2}$ resulted in a significant reduction in cyanobacteria levels in nearly all experiments (10 of 11), reducing their relative abundance from, on average, $85 \%$ to $29 \%$ of the total phytoplankton community with Planktothrix being highly sensitive, Microcystis being moderately sensitive, and Cylindrospermopsis being most resistant. Concurrently, eukaryotic algal levels increased in $75 \%$ of experiments. The bacterial phyla Actinobacteria, cyanobacteria, Planctomycetes, and Verrucomicrobia were most negatively impacted by $\mathrm{H}_{2} \mathrm{O}_{2}$, with Actinobacteria being the most sensitive. The ability of $\mathrm{H}_{2} \mathrm{O}_{2}$ to reduce, but not fully eliminate, cyanobacteria from the eutrophic water bodies studied here suggests it may not be an ideal mitigation approach in high biomass ecosystems.
\end{abstract}

Keywords: cyanobacteria; hydrogen peroxide; 16S rRNA; harmful algal blooms

Key Contribution: Use of high throughput DNA sequencing of the 16s RNA gene to quantify the effects of $\mathrm{H}_{2} \mathrm{O}_{2}$ on cyanobacteria and non-target prokaryotic plankton.

\section{Introduction}

Cyanobacteria, or blue-green algae, are photosynthetic prokaryotes that are ubiquitous in fresh and marine waterbodies. Blooms of cyanobacteria in eutrophic waters can be associated with light attenuation and hypoxia, and some bloom-forming cyanobacteria are capable of producing a suite of toxins, most commonly the hepatotoxin, microcystin [1]. Consequently, the World Health Organization (WHO) and US EPA have set drinking water and bathing guidance values microcystin [2,3]. In addition to exposure through drinking water and bathing, cyanotoxins can be ingested through the consumption of fish and shellfish [4-6]. These toxins can also affect animals; between 2007 and 2011, there were 67 cases of dog poisonings due to toxic cyanobacteria blooms across the U.S., 38 of which were fatal [7].

The occurrence of harmful cyanobacterial blooms is often linked to excessive anthropogenic eutrophication $[5,8,9]$ but reducing nutrient loads can be a difficult and lengthy process that can involve changing fertilizer and wastewater disposal practices. Hence, there is interest in identifying mitigation approaches that can selectively target and remove toxic cyanobacterial blooms in order to prevent 
exposure and harm. Hydrogen peroxide $\left(\mathrm{H}_{2} \mathrm{O}_{2}\right)$ has been considered for this role [10-12]. As a strong oxidant, it is known for its disinfectant capabilities, is a naturally occurring compound in aquatic systems, and quickly decomposes into water and gaseous oxygen [13]. $\mathrm{As}_{2} \mathrm{H}_{2}$ decomposes, it releases hydroxyl radicals, strong reactive oxygen species known to damage cells and inhibit photosynthetic activity by causing damage to photosystem II $[14,15] . \mathrm{H}_{2} \mathrm{O}_{2}$ has been shown to be specifically detrimental to the growth and function of cyanobacteria and capable of reducing biomass of Microcystis and Planktothrix by $50 \%$ in less than $48 \mathrm{~h}[10,11]$. Cyanobacteria are known to be more sensitive to $\mathrm{H}_{2} \mathrm{O}_{2}$ than eukaryotic primary producers $[13,14,16]$, and a previous study found Microcystis aeruginosa to be ten-times more sensitive than species of green algae and diatoms [13]. This may be due, in part, to the photosystems of cyanobacteria not being protected within an organelle [14]. In addition, unlike cyanobacteria, eukaryotic phytoplankton commonly produce enzymes such as ascorbate peroxidase that break down $\mathrm{H}_{2} \mathrm{O}_{2}$ and protect them from damage by reactive oxygen species (ROS) such as hydroxyl radicals [17]. A whole lake study examining mesozooplankton abundances, mostly Daphnia and Diaphanosoma, found that they were unaffected at $2 \mathrm{mg} \mathrm{H}_{2} \mathrm{O}_{2} \mathrm{~L}^{-1}$, a concentration that inhibited the cyanobacterium Planktothrix [11].

The effects of hydrogen peroxide on cyanobacteria has been well-documented in laboratory cultures $[13,18,19]$. However, research assessing the effect of $\mathrm{H}_{2} \mathrm{O}_{2}$ on other important members of planktonic communities such as picocyanobacteria, eukaryotes, and heterotrophic bacteria has been limited. It is important that effects of $\mathrm{H}_{2} \mathrm{O}_{2}$ on cyanobacteria and the rest of the prokaryotic and eukaryotic community are understood before $\mathrm{H}_{2} \mathrm{O}_{2}$ is widely used for mitigation purposes in natural ecosystems.

This project, therefore, sought to understand the effects of $\mathrm{H}_{2} \mathrm{O}_{2}$ on multiple genera of toxin-producing cyanobacteria (i.e., Microcystis, Dolichospermum, Cylindrospermopsis, and Planktothrix) as well as co-occurring plankton including picocyanobacteria, eukaryotic algae, and heterotrophic bacteria. This was done through a series of incubation experiments performed using environmental samples from four contrasting water bodies across Long Island, NY, USA. Microbial communities were assessed using standard (microscopy, fluorometry) and molecular (high throughput amplicon sequencing) approaches to establish a comprehensive assessment of the efficacy of $\mathrm{H}_{2} \mathrm{O}_{2}$ as a mitigation approach for toxic cyanobacterial blooms.

\section{Results}

\subsection{Fluorometric Response of the Phytoplankton Community}

During three experiments utilizing water from Lake Agawam, initial cyanobacterial biomass ranged from 73 to $243 \mu \mathrm{g}$ Chla $\mathrm{L}^{-1}$, dominated by mixtures of Microcystis, Planktothrix, and Dolichospermum. Cyanobacterial biomass was significantly lower four to six days after exposure to $4 \mathrm{mg} \mathrm{H}_{2} \mathrm{O}_{2} \mathrm{~L}^{-1}$ in two of three experiments, with concentrations $52 \%(p<0.001$; Figure $1 \mathrm{a})$ and $43 \%$ $(p<0.005$; Figure 1c) lower than the control. Cyanobacterial biomass was reduced below the New York State Department of Environmental Conservation (NYSDEC) level of concern of $25 \mu \mathrm{g} \mathrm{Chla} \mathrm{L}{ }^{-1}$

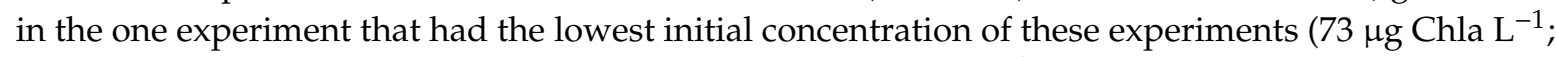
Figure 1a). Initial green algal biomass was low $\left(0-0.24 \mu \mathrm{g} \mathrm{Chla}^{-1}\right)$ but was significantly higher than the control following exposure to $\mathrm{H}_{2} \mathrm{O}_{2}$ in one of the experiments $(p<0.001$; Figure 1a). Unicellular brown algae were fluorometrically undetectable during the Lake Agawam experiments.

Initial cyanobacterial biomass for the three Mill Pond experiments ranged from 45 to $366 \mu \mathrm{g} \mathrm{Chla} \mathrm{L}{ }^{-1}$, dominated by Microcystis and Cylindrospermopsis. Four or seven days after exposure to $\mathrm{H}_{2} \mathrm{O}_{2}$, cyanobacterial biomass was significantly lower than the control in all three experiments by $99 \%(p<0.001$; Figure 1d), 93\% ( $p<0.001$; Figure 1e), and 95\% ( $p<0.001$; Figure 1f), respectively, and below the level of concern of $25 \mu \mathrm{g}$ Chla L ${ }^{-1}$ in two experiments (Figure $1 \mathrm{~d}, \mathrm{f}$ ). Initial biomass of green algae in Mill Pond ranged from below detection to $7.3 \mu \mathrm{g}$ Chla $\mathrm{L}^{-1}$ and rose higher than the control to $76 \pm 7 \mu \mathrm{g}$ Chla $\mathrm{L}^{-1}$ $\left(p<0.001\right.$; Figure 1d), $30 \pm 2 \mu$ Chla L $^{-1}\left(p<0.001\right.$; Figure 1e), and $342 \pm 18 \mu$ Chla L $^{-1}(p<0.001$; 
Figure 1f), respectively, in all three experiments following $\mathrm{H}_{2} \mathrm{O}_{2}$ exposure. Initial unicellular brown algae biomass levels were below detection at the start of the three experiments, but values rose significantly to $5 \pm 1 \mu \mathrm{g}$ Chla L ${ }^{-1}(p<0.005)$ and $24 \pm 3 \mu \mathrm{g}$ Chla L $^{-1}(p<0.001)$ in two of the three experiments, but remained undetectable in the third experiment (Figure 1d,f).

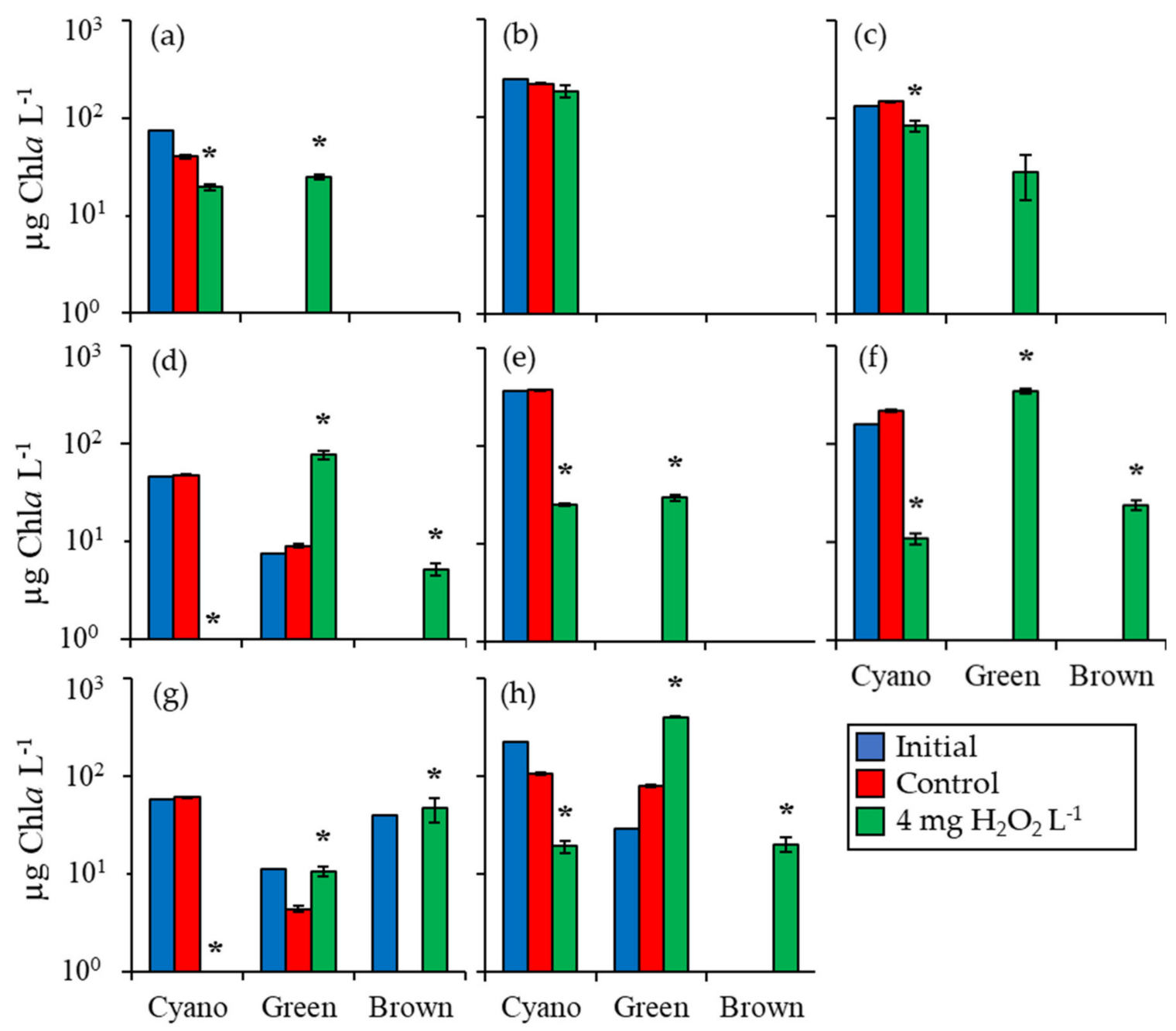

Figure 1. Fluoroprobe biomass measurements for bottle experiments from Lake Agawam (a) 7/21/16, (b) 10/20/16, (c) 6/9/17; Mill Pond (d) 7/21/16, (e) 10/20/16, (f) 6/30/17; (g) Georgica Pond 7/21/16; and (h) Roth Pond 6/9/17. Asterisks show significant changes $(p<0.05)$ in treatments relative to control. Error bars show standard error.

For the Georgica Pond experiment, initial cyanobacterial biomass was $58 \mu \mathrm{g}$ Chla $\mathrm{L}^{-1}$ being dominated by Aphanizomenon (Figure 1g). Four days after treatment with $4 \mathrm{mg} \mathrm{H}_{2} \mathrm{O}_{2} \mathrm{~L}^{-1}$, cyanobacterial biomass was $99.8 \%$ lower than the control and nearly $0 \mu \mathrm{g}$ Chla $\mathrm{L}^{-1}(p<0.001$; Figure $1 \mathrm{~g})$. Initial green algal biomass was $11 \mu \mathrm{g}$ Chla L${ }^{-1}$ and was $144 \%$ higher than the control following exposure to $\mathrm{H}_{2} \mathrm{O}_{2}$ $\left(p<0.01\right.$; Figure 1g). Initial unicellular brown algae biomass was $39 \mu \mathrm{g} \mathrm{Chla} \mathrm{L}^{-1}$ and rose to $47 \pm$ $13 \mu \mathrm{g}$ Chla L ${ }^{-1}$ following $\mathrm{H}_{2} \mathrm{O}_{2}$ exposure, significantly higher than the control where concentration had fallen $(p<0.05$; Figure 1g).

For the Roth Pond experiment, initial cyanobacterial biomass was $222 \mu \mathrm{g} \mathrm{Chla} \mathrm{L}^{-1}$ and was dominated by Microcystis and Cylindrospermopsis (Figure 1h). Cyanobacterial biomass was $82 \%$ lower than the control $(p<0.001)$ at $19 \pm 3 \mu \mathrm{g}$ Chla $\mathrm{L}^{-1}$ in the $4 \mathrm{mg} \mathrm{H}_{2} \mathrm{O}_{2} \mathrm{~L}^{-1}$ treatment after six days. Initial green algae biomass was $29 \mu \mathrm{g}$ Chla L ${ }^{-1}$ but rose in the $\mathrm{H}_{2} \mathrm{O}_{2}$ treatment to $403 \pm 10 \mu \mathrm{g}$ Chla L ${ }^{-1}, 400 \%$ higher than the control $(p<0.001$; Figure $1 \mathrm{~h})$. Unicellular brown algae were undetectable at the start of 
the experiment but were significantly higher than the control at $20 \pm 3 \mu \mathrm{g}$ Chla L $\mathrm{L}^{-1} 6$ days after $\mathrm{H}_{2} \mathrm{O}_{2}$ exposure $(p<0.005$; Figure 1h).

In summary, during the eight incubation experiments among four locations assessed fluorometrically, cyanobacterial levels were significantly lowered following the addition of $\mathrm{H}_{2} \mathrm{O}_{2}$ than the control in seven experiments, green algae levels became significantly higher in $\mathrm{H}_{2} \mathrm{O}_{2}$ treatments relative to the control in six of eight experiments, and unicellular brown algae became significantly higher in $\mathrm{H}_{2} \mathrm{O}_{2}$ treatments relative to the control in four of eight experiments.

\subsection{Detailed Assessment of Planktonic Responses to $\mathrm{H}_{2} \mathrm{O}_{2}$}

Given the strong and significant effects of $\mathrm{H}_{2} \mathrm{O}_{2}$ on plankton communities during this first set of experiments, three additional experiments were performed utilizing water from three ecosystems with additional analyses performed to more fully assess the response of plankton communities to $\mathrm{H}_{2} \mathrm{O}_{2}$. In the first of these experiments from Lake Agawam, the initial cyanobacterial biomass was

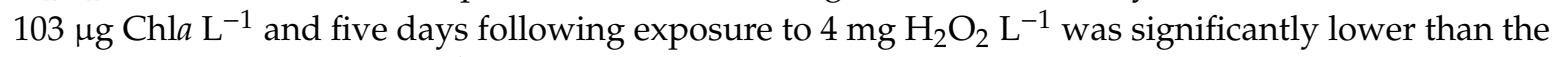

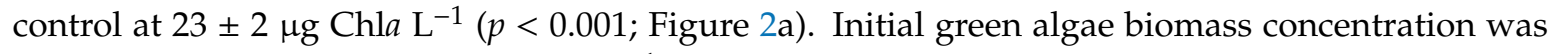
undetectable but rose to $69 \pm 4 \mu \mathrm{g} C h l a \mathrm{~L}^{-1}$ after treatment with $\mathrm{H}_{2} \mathrm{O}_{2}$, a level significantly higher than the control $(p<0.001$; Figure 2a). Unicellular brown algae biomass was undetectable at the start of the experiment but rose to levels significantly higher than the control at $0.4 \pm 0.2 \mu \mathrm{g} \mathrm{Chl} a \mathrm{~L}^{-1}$ in the $\mathrm{H}_{2} \mathrm{O}_{2}$ treatment $(p<0.05$; Figure 2a). Picocyanobacteria (Cyanobium) concentrations in Lake Agawam were initially $5340 \pm 360$ cells mL $\mathrm{mL}^{-1}$ and decreased in the control to $1690 \pm 80$ cells mL $^{-1}$ (Figure $2 \mathrm{~b}$ ). The $\mathrm{H}_{2} \mathrm{O}_{2}$ treatment was reduced by less, and was $110 \%$ higher relative to the control with a final concentration of $3560 \pm 90$ cells mL ${ }^{-1}(p<0.001$; Figure 2b). Eukaryotic algae concentrations were $193 \%$ higher in the $\mathrm{H}_{2} \mathrm{O}_{2}$ treatment than the control at $9090 \pm 150$ cells mL ${ }^{-1}(p<0.001$; Figure 2b). The initial concentration of heterotrophic bacteria was $7.0 \times 10^{5}$ cells $\mathrm{mL}^{-1}$ and was $44 \%$ lower than the control after the addition of $\mathrm{H}_{2} \mathrm{O}_{2}$ at $3.45 \times 10^{5}$ cells mL $\mathrm{m}^{-1}(p<0.001$; Figure $2 \mathrm{~b})$. Diatom densities in Lake Agawam were 34 cells $\mathrm{mL}^{-1}$ and levels rose to be significantly higher in the treatment $(p<0.05)$ relative to the control to $120 \pm 28$ cells $\mathrm{mL}^{-1}$ (Figure 2c). Green algae concentrations were initially 657 cells $\mathrm{mL}^{-1}$ and were nearly six-fold higher in the treatment compared to the control at $3700 \pm 50$ cells $\mathrm{mL}^{-1}$ $\left(p<0.001\right.$; Figure 2c). Initial Microcystis concentrations were 222 colonies $\mathrm{mL}^{-1}$ and were significantly reduced by $\mathrm{H}_{2} \mathrm{O}_{2}$ to below the control to $34 \pm 7$ colonies $\mathrm{mL}^{-1}(p<0.001$; Figure $2 \mathrm{c}$ ). There were 76 Dolichospermum chains $\mathrm{mL}^{-1}$ at the start of the experiment and concentrations sharply declined to $4 \pm 4$ chains $\mathrm{mL}^{-1}$ following $\mathrm{H}_{2} \mathrm{O}_{2}$ addition, a level significantly lower than the control $(p<0.005$; Figure 2c). Finally, following $\mathrm{H}_{2} \mathrm{O}_{2}$ addition Planktothrix concentrations were $50 \%$ of the control at $439 \pm 43$ chains $\mathrm{mL}^{-1}$ ( $p<0.01$; Figure 2c).

High throughput sequencing of the $16 \mathrm{~S}$ rDNA gene indicated that the relative abundance of Actinobacteria in Lake Agawam was initially $17 \pm 1 \%$ and dropped to $5 \pm 1 \%$ five days after exposure to $4 \mathrm{mg} \mathrm{H}_{2} \mathrm{O}_{2} \mathrm{~L}^{-1}$, significantly lower than the control $(p<0.001)$. Planctomycetes was $4 \pm 1 \%$ initially and was significantly reduced to $2 \pm 1 \%$, significantly lower than the control $(p<0.001)$, while Verrucomicrobia was $4 \pm 1 \%$ and was reduced to $0.4 \pm 0.1 \%$, significantly lower than the control $(p<$ 0.001; Figure 2d). The sequenced relative abundance of Bacteroidetes in Lake Agawam was significantly higher than the control after the addition of $\mathrm{H}_{2} \mathrm{O}_{2}$ at $42 \pm 4 \%$ compared to an initial of $32 \pm 1 \%(p<$ 0.001; Figure 2d). The sequenced relative abundance of Proteobacteria and other less abundant taxa abundances were not significantly altered by $\mathrm{H}_{2} \mathrm{O}_{2}$ (Figure 2d). 

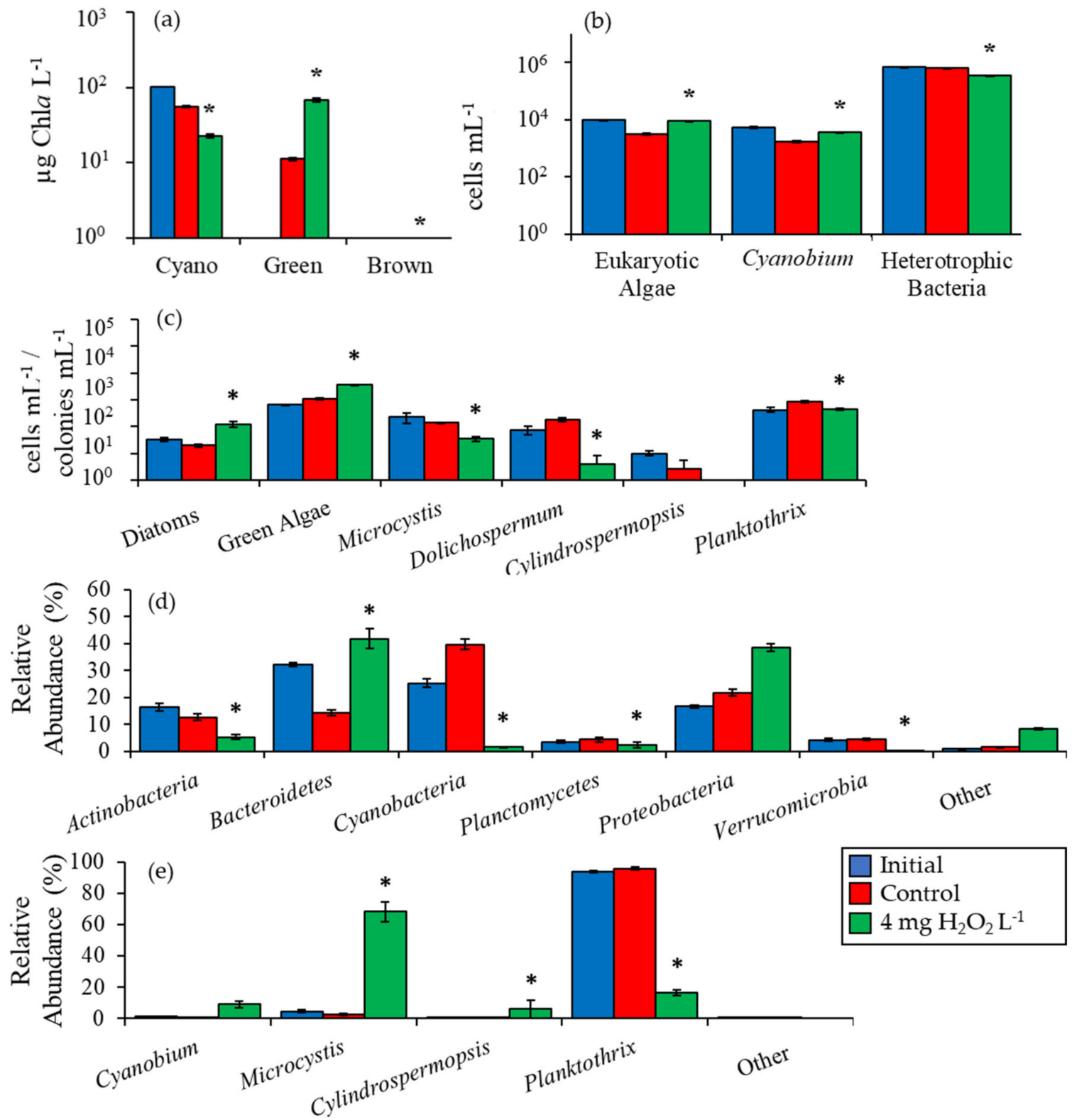

Figure 2. (a) Fluoroprobe biomass, (b) flow cytometry, (c) microscopy, (d) phylum level relative abundance, and (e) genus level cyanobacteria relative abundance for Lake Agawam experiment, $10 / 3 / 16$. Asterisks show significant changes $(p<0.05)$ in treatments relative to control. Error bars show standard error.

Among all prokaryotes, the sequenced relative abundance of cyanobacteria was initially $25 \pm 2 \%$ but was reduced to lower than the control to $2 \pm 1 \%$ after $\mathrm{H}_{2} \mathrm{O}_{2}$ exposure $(p<0.001)$. Among the cyanobacteria, Planktothrix was the most abundant taxa in the Lake Agawam experiment with an initial relative abundance of $94 \pm 1 \%$ that was significantly lower than the control at $17 \pm 2 \%$ following the addition of $\mathrm{H}_{2} \mathrm{O}_{2}(p<0.001$; Figure 2e). In contrast, Microcystis had an initial abundance of $4 \pm 1 \%$ that was higher relative to the control at $68 \pm 6 \%$ in the $\mathrm{H}_{2} \mathrm{O}_{2}$ treatment $(p<0.001$; Figure 2e).

Cylindrospermopsis made up only $0.2 \pm 0.1 \%$ of initial cyanobacterial sequences but was higher than the control at $6 \pm 6 \%$ following the $\mathrm{H}_{2} \mathrm{O}_{2}$ addition ( $p<0.001$; Figure 2e). Multiplying cyanobacterial $\mathrm{Chl} a$ values by sequenced relative abundances provided an estimate of individual biomasses and revealed that Planktothrix biomass decreased significantly $(p<0.001)$, while Microcystis $(p<0.001)$ and Cylindrospermopsis $(p<0.001)$ biomasses increased (Figure 3). 


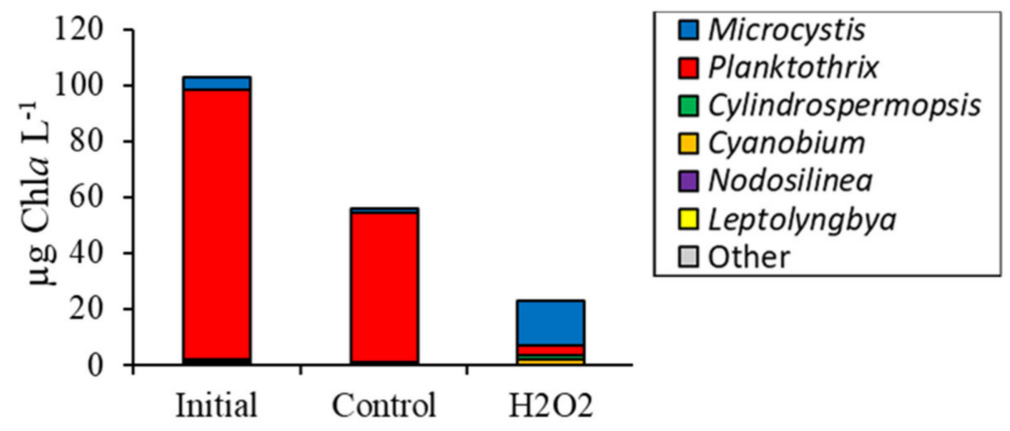

Figure 3. Absolute abundance (relative abundance multiplied by biomass) of cyanobacteria for Lake Agawam experiment, 10/3/16.

For the experiment that provided a detailed assessment from the Mill Pond planktonic community,

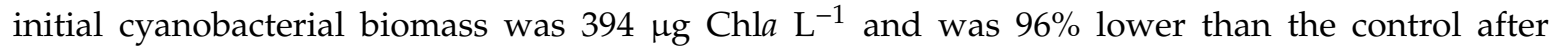

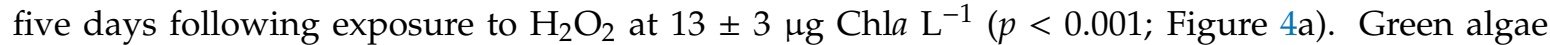
were below detectable levels in Mill Pond at the start of the experiment but were significantly higher at $60 \pm 7 \mu \mathrm{g}$ Chla $\mathrm{L}^{-1}(p<0.001)$ following $\mathrm{H}_{2} \mathrm{O}_{2}$ treatment; unicellular brown algae were fluorometrically undetectable in this experiment (Figure 4a). Initial eukaryotic algae concentrations were $1.14 \pm 0.30 \times 10^{4}$ cells mL $\mathrm{m}^{-1}$ and were unchanged by $\mathrm{H}_{2} \mathrm{O}_{2}$ but were $52 \%$ lower relative to the control $(p<0.001$; Figure 4 b).

Cyanobium and heterotrophic bacteria concentrations in the $\mathrm{H}_{2} \mathrm{O}_{2}$ treatment were not significantly different from the control (Figure $4 \mathrm{~b}$ ). Levels of diatoms were low in Mill Pond prior to the experiment $\left(<10\right.$ cells $\mathrm{mL}^{-1}$ ) but increased and were significantly higher than the control after the $\mathrm{H}_{2} \mathrm{O}_{2}$ addition with a final concentration of $157 \pm 35$ cells $\mathrm{mL}^{-1}(p<0.01$; Figure $4 \mathrm{c})$. Green algae cell densities were initially $1290 \pm 140$ cells mL $\mathrm{m}^{-1}$ and were significantly higher in the $\mathrm{H}_{2} \mathrm{O}_{2}$ treatment compared to the control at $2.65 \pm 0.37 \times 10^{4}$ cells $\mathrm{mL}^{-1}(p<0.01$; Figure 4c). Initial Microcystis concentrations were $108 \pm 4$ colonies $\mathrm{mL}^{-1}$ and were significantly lower than the control following exposure to $\mathrm{H}_{2} \mathrm{O}_{2}$ $\left(p<0.05\right.$; Figure 4c). Cylindrospermopsis initial concentration was $2.45 \pm 0.14 \times 10^{5}$ chains $\mathrm{mL}^{-1}$ and significantly decreased by $100 \%$ following exposure to $\mathrm{H}_{2} \mathrm{O}_{2}(p<0.001$; Figure $4 \mathrm{c})$ while Dolichospermum and Planktothrix levels were unaffected.

High throughput sequencing revealed that $\mathrm{H}_{2} \mathrm{O}_{2}$ caused a significant decline in the sequenced relative abundance of several bacterial groups in Mill Pond including Actinobacteria, Planctomycetes, and Verrucomicrobia ( $p<0.005$; Figure $4 \mathrm{~d})$. In contrast, the sequenced relative abundances of Bacteroidetes and Proteobacteria were higher in the $\mathrm{H}_{2} \mathrm{O}_{2}$ treatment relative to the control ( $p<0.001$; Figure $4 \mathrm{~d}$ ). Among cyanobacteria identified via sequencing of $16 \mathrm{~S}$ rDNA, Cylindrospermopsis was the dominant operational taxonomic unit (OTU) $(88 \pm 1 \%$ of cyanobacteria sequences) in initial sequences and increased in relative abundance following $\mathrm{H}_{2} \mathrm{O}_{2}$ addition to $98 \pm 1 \%$, significantly higher than the control $(p<0.001)$. In contrast, the sequenced relative abundances of Microcystis and Nodosilinea were significantly lowered by $\mathrm{H}_{2} \mathrm{O}_{2}$ relative to the control $(p<0.001$; Figure $4 \mathrm{e})$. Estimated changes in absolute abundances based on fluorometry and sequencing revealed that, despite the differential sensitivities of differing cyanobacterial groups to $\mathrm{H}_{2} \mathrm{O}_{2}$, the biomass of Cylindrospermopsis $(p<0.001)$, Microcystis $(p<0.01)$, and Nodosilinea $(p<0.001)$ all significantly declined in the treatment relative to the initial levels and the control (Figure 5).

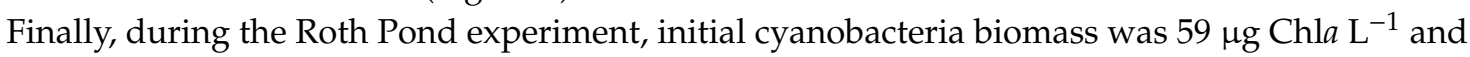
was significantly lower in $\mathrm{H}_{2} \mathrm{O}_{2}$ treatments at $39 \pm 3 \mu \mathrm{g} C h l a \mathrm{~L}^{-1}$ relative to the control seven days after

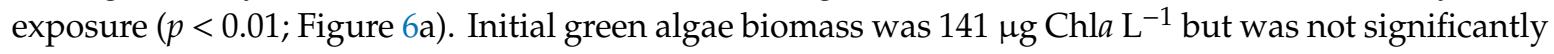
altered by $\mathrm{H}_{2} \mathrm{O}_{2}$, while unicellular brown algal biomass levels were $100 \%$ higher in the $\mathrm{H}_{2} \mathrm{O}_{2}$ treatment

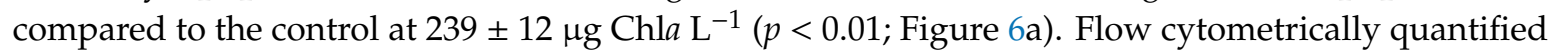
Cyanobium concentrations in the Roth Pond were 99.8\% lower in the $\mathrm{H}_{2} \mathrm{O}_{2}$ treatment compared to the control $(p<0.001)$ whereas levels of eukaryotic algae were unchanged (Figure 6b). Levels of 
heterotrophic bacteria were 33\% higher than the controls seven days after the addition of $_{2} \mathrm{H}_{2} \mathrm{O}_{2}$ $(p<0.005$; Figure $6 b)$. Green algae identified microscopically were $111 \%$ higher in the $\mathrm{H}_{2} \mathrm{O}_{2}$ treatment compared to the control at $1.28 \pm 0.06 \times 10^{5}$ cells mL $\mathrm{mL}^{-1}(p<0.001$; Figure $6 \mathrm{c})$, while diatom levels were unchanged (Figure 6c). Microcystis concentrations were $1320 \pm 180$ colonies $\mathrm{mL}^{-1}$ and were reduced by $100 \%$ by $\mathrm{H}_{2} \mathrm{O}_{2}(p<0.001)$ while Dolichospermum concentrations were unchanged (Figure $\left.6 c\right)$. Final, total concentration of microcystin was $0.56 \pm 0.13 \mu \mathrm{g} \mathrm{L}^{-1}$ in the control, and significantly higher at 0.85 $\pm 0.06 \mu \mathrm{g} \mathrm{L}-1$ in the $\mathrm{H}_{2} \mathrm{O}_{2}$ treatment $(p<0.005)$.
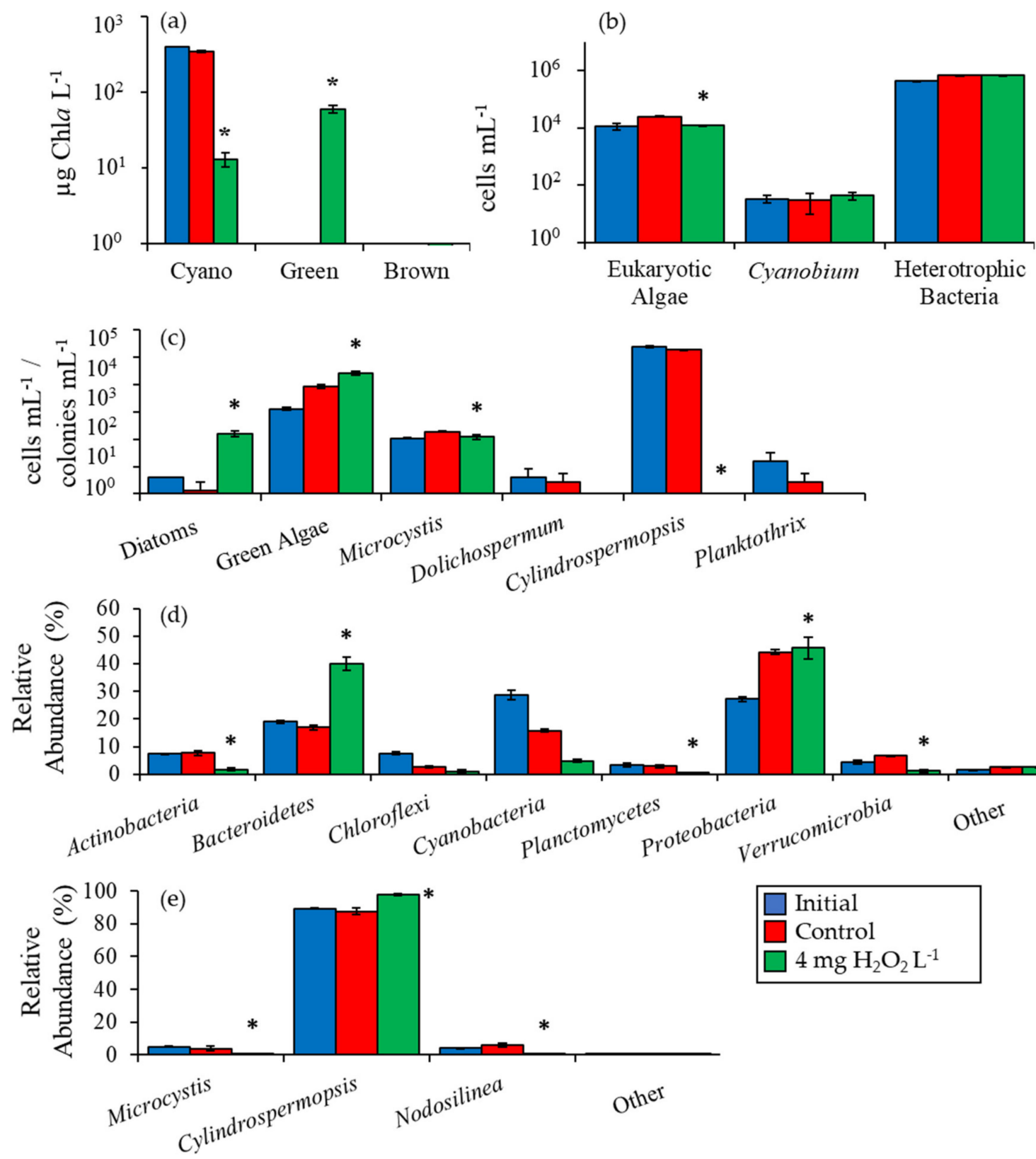

Figure 4. (a) Fluoroprobe biomass, (b) flow cytometry, (c) microscopy, (d) phylum level relative abundance, and (e) genus level cyanobacteria relative abundance for Mill Pond experiment, 10/3/16. Asterisks show significant changes $(p<0.05)$ in treatments relative to control. Error bars show standard error. 


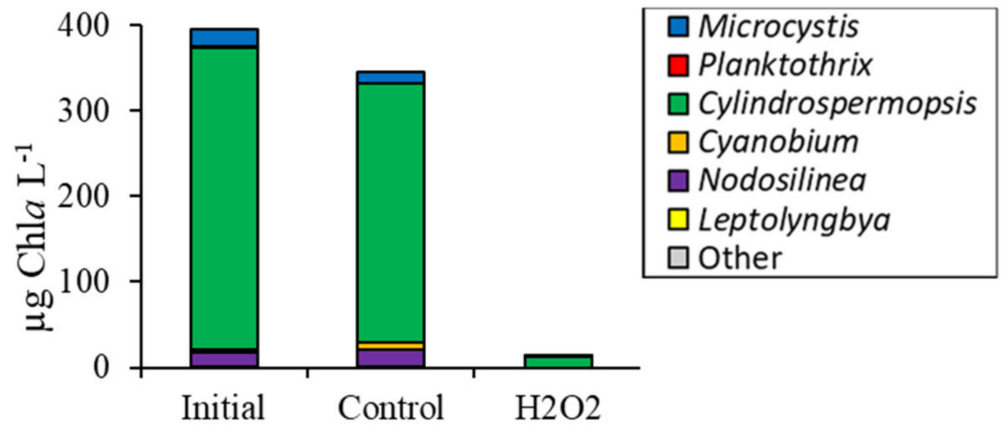

Figure 5. Absolute abundance (relative abundance multiplied by biomass) of cyanobacteria for Mill Pond experiment 10/3/16.
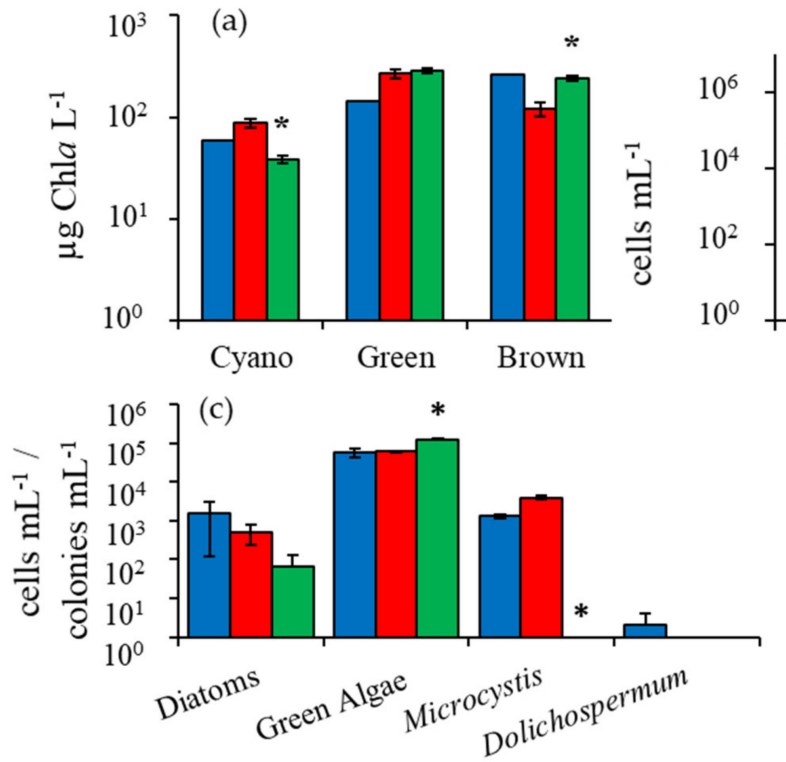

(b)

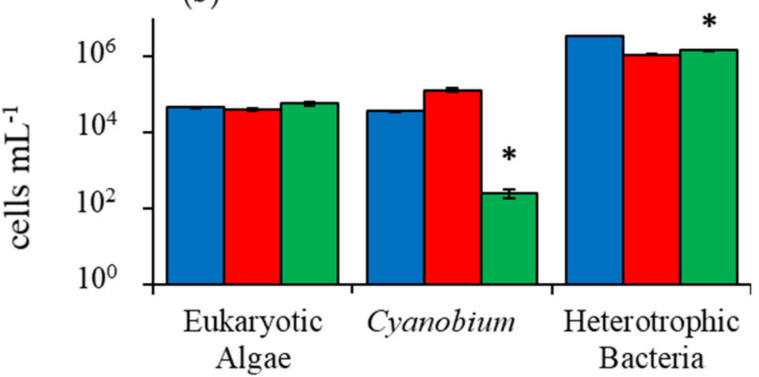

$\square$ Initial

$\square$ Control

$4 \mathrm{mg} \mathrm{H}_{2} \mathrm{O}_{2} \mathrm{~L}^{-1}$
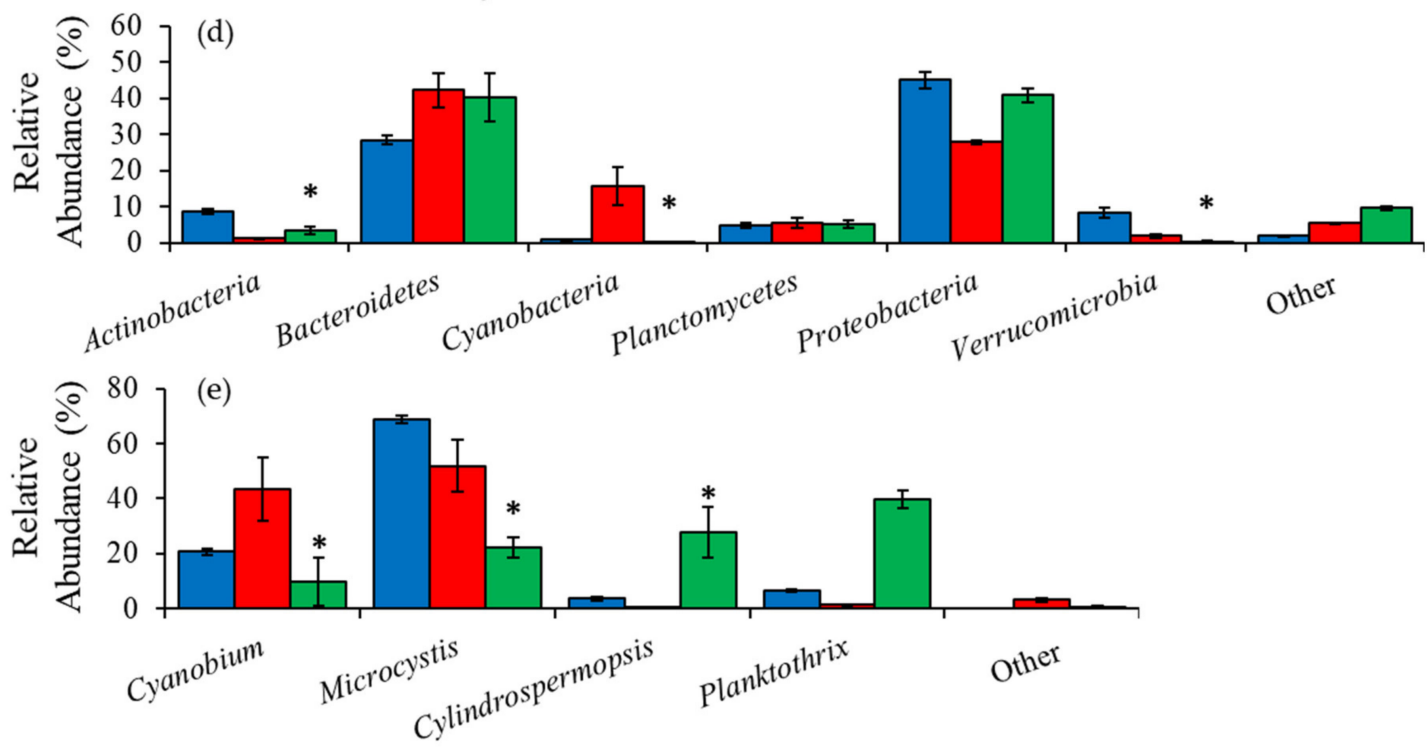

Figure 6. (a) Fluoroprobe biomass, (b) flow cytometry, (c) microscopy, (d) phylum level relative abundance, and (e) genus level cyanobacteria relative abundance for Roth Pond experiment, 6/30/17. Asterisks show significant changes $(p<0.05)$ in treatments relative to control. Error bars show standard error. 
Sequencing of the 16S rDNA indicated Actinobacteria were significantly higher in the $\mathrm{H}_{2} \mathrm{O}_{2}$ treatment compared to the control $(p<0.001)$ whereas cyanobacteria and Verrucomicrobia relative abundances were significantly lower than the control $(p<0.001$; Figure 6e). Among the cyanobacteria, Microcystis and Cyanobium were the two most abundant genera in Roth Pond and the relative abundance of both was lower in the $\mathrm{H}_{2} \mathrm{O}_{2}$ treatment compared to the control ( $p<0.001$; Figure 6e). In contrast, Cylindrospermopsis relative abundance was initially $4 \pm 1 \%$ and increased to $28 \pm 9 \%$ following in the $\mathrm{H}_{2} \mathrm{O}_{2}$ treatment and was significantly higher than the control $(p<0.001)$. Despite the lower relative and absolute abundances of Microcystis during this experiment, the concentration of the cyanotoxin, microcystin, was marginally higher in the $\mathrm{H}_{2} \mathrm{O}_{2}$ treatment than the control, at $0.9 \pm 0.1 \mu \mathrm{g}$ $\mathrm{L}^{-1}$ compared to $0.6 \pm 0.1 \mu \mathrm{g} \mathrm{L}{ }^{-1}(p<0.05)$. The individual biomasses (relative abundance multiplied by cyanobacterial Chla) for Microcystis $(p<0.05)$ and Cyanobium $(p<0.005)$ significantly declined in response to $\mathrm{H}_{2} \mathrm{O}_{2}$, while total biomass of Planktothrix $(p<0.01)$ and Cylindrospermopsis $(p<0.1)$ increased (Figure 7).

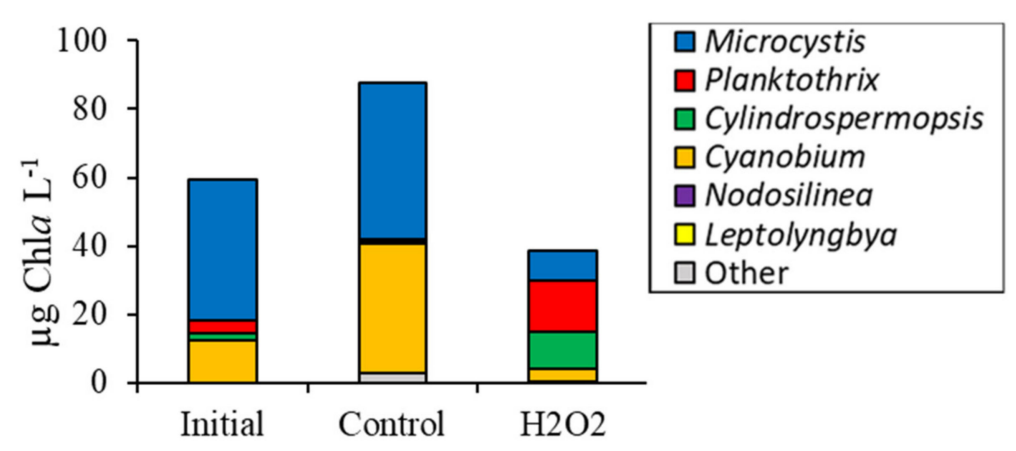

Figure 7. Absolute abundance (relative abundance multiplied by biomass) of cyanobacteria for Roth Pond experiment, 6/30/17.

\section{Discussion}

During this study, $\mathrm{H}_{2} \mathrm{O}_{2}$ was used to mitigate cyanobacterial populations in environmental samples from four water bodies. $\mathrm{H}_{2} \mathrm{O}_{2}$ almost always reduced the levels of cyanobacteria and increased the abundances of eukaryotic algae. Effects on non-photosynthetic prokaryotes were complex, as some bacteria were consistently inhibited by $\mathrm{H}_{2} \mathrm{O}_{2}$ while others were promoted. Collectively, these findings provide new insight into the complex manner in which $\mathrm{H}_{2} \mathrm{O}_{2}$ can alter the composition of microbial communities dominated by cyanobacteria.

\subsection{Cyanobacteria vs. Eukaryotes}

Cyanobacterial biomass and cell abundance were significantly reduced by $\mathrm{H}_{2} \mathrm{O}_{2}$ in a majority of experiments $(91 \%, 10$ of 11), and eukaryotic green and unicellular brown algae were significantly increased in $73 \%$ and $55 \%$ of experiments, and did not decline significantly in any experiment. The ability of $\mathrm{H}_{2} \mathrm{O}_{2}$ to significantly reduce concentrations of cyanobacteria relative to eukaryotic algae is consistent with previous observations $[11,13,14]$. Across all experiments, the fluorometric relative abundance of cyanobacteria was significantly reduced from $85 \pm 8 \%$ to $29 \pm 10 \%(p<0.005)$. The trend was also reflected in microscopy, with significant cyanobacterial reductions and significant increases of eukaryotic algae in all experiments quantified. Differences in flow cytometry were more varied, with Cyanobium and eukaryotic algae counts each significantly lower than control in one experiment, and significantly higher in another. A lack of ascorbate peroxidases in cyanobacteria, which are common in eukaryotes, has been offered as one possible factor contributing to their greater sensitivity $[20,21]$. Additionally, photosystem II of cyanobacteria is not protected within a cell organelle, making it physically more susceptible to damage from $\mathrm{H}_{2} \mathrm{O}_{2}$ [22].

Despite the common reduction in cyanobacterial biomass in experiments, it was reduced to

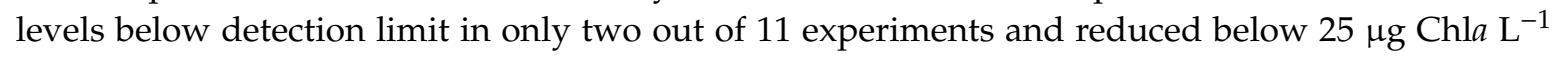


(NYSDEC guidance value for cyanobacterial blooms) in one other. The inability to completely eliminate cyanobacteria may result in their resurgence over a short period of time [11]. While microcystin was only quantified once in this study, whole-water concentrations slightly increased $\left(0.6\right.$ to $\left.0.9 \mu \mathrm{g} \mathrm{L}^{-1}\right)$ in that experiment, a finding that slightly contrasts with prior studies [11] but is perhaps not completely surprising given the dynamics of cyanobacteria in that experiment. While total cyanobacterial biomass decreased in that experiment, it was one of the smallest declines in this study (33\%). Further, while one microcystin producer, Microcystis [1], significantly declined in relative abundance during that experiment, another, Planktothrix [1], significantly increased and seemingly contributed to the slightly higher toxicity observed at the end of this experiment.

\subsection{Comparing Cyanobacterial Genera}

While cyanobacterial biomass and cell densities were reduced in a majority of experiments, the reductions varied between genera. Although cyanobacteria do not usually produce ascorbate peroxidases, they are capable of producing a suite of other anti-oxidant enzymes, including catalases, peroxidases, and peroxiredoxins [21]. While peroxiredoxins are ubiquitously present across cyanobacteria, other enzymes can vary between genera and strains, which may account for some of the variability in relative reductions observed [21].

Microcystis was the most ubiquitous of the cyanobacteria during this study and was significantly reduced in microscopic counts to levels less than control in all experiments, but was reduced below detection in only one. Microcystis was reduced to a significantly lower relative and absolute abundance compared to the unamended controls in two of the three experiments where sequencing was performed and was higher with $\mathrm{H}_{2} \mathrm{O}_{2}$ in the experiment where Planktothrix was dominant. In contrast to Microcystis, Cyanobium and Cylindrospermopsis were more resistant to $\mathrm{H}_{2} \mathrm{O}_{2}$. Cyanobium was the second most abundant cyanobacteria in Roth Pond, behind Microcystis, and cell concentrations were significantly lower relative to the control in one experiment, and significantly higher in another. The sequenced relative abundance of Cyanobium was significantly lower in one of the three experiments. A prior laboratory study found Cyanobium four-fold less sensitive to $\mathrm{H}_{2} \mathrm{O}_{2}$ than Microcystis [13]. Cylindrospermopsis concentrations in microscopy were detected in two experiments, and were significantly reduced in only one (Figure $4 \mathrm{c}$ ). The sequenced relative abundance of Cylindrospermopsis in $\mathrm{H}_{2} \mathrm{O}_{2}$ treatments was higher than the control in all three experiments, including one where it was dominant over Microcystis, though it was still reduced in absolute abundance (Figures $4 \mathrm{c}$ and 5).

The heightened sensitivity of Microcystis to $\mathrm{H}_{2} \mathrm{O}_{2}$ relative to other genera may be related to its deficient antioxidant systems as some strains of Microcystis lack typical cyanobacterial catalases [21]. Importantly, however, while Microcystis densities were significantly reduced by initial treatment with $\mathrm{H}_{2} \mathrm{O}_{2}$, it often remained one of the most abundant cyanobacterial genera in experiments where it dominated and was never fully eliminated. Microcystis commonly forms large globular colonies with cells embedded in and surrounded by polysaccharide mucous [23]. The extracellular polymeric substances of this mucous have strong $\mathrm{H}_{2} \mathrm{O}_{2}$ scavenging abilities and provide an antioxidant buffer for the cells within [24]. This additional protection may partly explain the perseverance of Microcystis during experiments. In addition, it has been shown that some strains of Microcystis incapable of microcystin synthesis have high levels of thioredoxin and peroxiredoxin, enzymes involved in $\mathrm{H}_{2} \mathrm{O}_{2}$ degradation [19] making these strains more likely to survive repeated $\mathrm{H}_{2} \mathrm{O}_{2}$ doses than toxic strains. Hence, the persistence of Microcystis may be partly facilitated by shifts among differing strains.

The relative $\mathrm{H}_{2} \mathrm{O}_{2}$ resistance of Cylindrospermopsis among cyanobacteria may be due, in part, to their ability to produce superoxide dismutase, catalase, and ascorbate peroxidase [25]. The ability to produce ascorbate peroxidase in Cylindrospermopsis is somewhat unique, as it was believed to be lacking in other cyanobacteria, and therefore contributes to the reduced effectiveness of peroxide against this genus $[17,20]$. In addition, Cylindrospermopsis can produce single cell akinetes which it uses to survive unfavorable conditions [26]. Akinete production may also account for differences between 
gene detection and microscopic counts where Cylindrospermopsis reduced was below microscopic detection, as the visible trichomes may have fragmented into akinetes or small, morphologically unidentifiable fragments [27]. It is unlikely the $16 \mathrm{~S}$ rDNA of Cylindrospermopsis persisted after the cells were destroyed by $\mathrm{H}_{2} \mathrm{O}_{2}$, as DNA often degrades within $24 \mathrm{~h}$ in freshwater [28,29].

Planktothrix dominated the Lake Agawam experiment that was examined in detail and displayed the largest relative decline in sequenced abundance of any microbe, dropping from $94 \%$ to $17 \%$ in the $\mathrm{H}_{2} \mathrm{O}_{2}$ treatment. In the Roth Pond experiment, Planktothrix increased slightly in relative and absolute abundance of sequences but was below detection levels in microscopic counts. $\mathrm{H}_{2} \mathrm{O}_{2}$ has been shown to be effective in controlling Planktothrix in lakes and ponds at similar concentrations to those used here $[11,30,31]$. This experiment where Planktothrix declined by nearly $80 \%$ in relative abundance was also the only instance when the sequenced relative abundance of Microcystis among the cyanobacteria increased following treatment with $\mathrm{H}_{2} \mathrm{O}_{2}$, despite its absolute decline, supporting the hypothesis that Planktothrix is more sensitive to $\mathrm{H}_{2} \mathrm{O}_{2}$ than Microcystis [30,32], and in assessing all available literature $[11,31,32]$, may be the most sensitive of the cyanobacterial genera to $\mathrm{H}_{2} \mathrm{O}_{2}$.

The collective response of these experiments leads evidence to support an 'open niche' hypothesis [33]. with regard to the effects of $\mathrm{H}_{2} \mathrm{O}_{2}$ on cyanobacteria. While different cyanobacteria are likely differentially sensitive to $\mathrm{H}_{2} \mathrm{O}_{2}$, it also seems that the effects of $\mathrm{H}_{2} \mathrm{O}_{2}$ are somewhat conditional upon the original community composition. That is, in many cases the dominant cyanobacterial genus is most reduced by $\mathrm{H}_{2} \mathrm{O}_{2}$, perhaps by providing the most organic surface area for the $\mathrm{H}_{2} \mathrm{O}_{2}$ to react with, allowing genera at lower relative abundances to fill the niche left open by the formerly dominant genera.

\subsection{Heterotrophic Bacteria}

The net effect of $\mathrm{H}_{2} \mathrm{O}_{2}$ on bacteria during this study was inconclusive, as concentrations of heterotrophic bacteria were significantly lower than the control in one of three experiments, and significantly higher in another. In contrast, high throughput sequencing of $16 \mathrm{~S}$ rDNA revealed that, beyond with changes in total bacterial densities, there were pronounced shifts within prokaryotic communities following treatment with $\mathrm{H}_{2} \mathrm{O}_{2}$. The prokaryote taxa identified here were categorized at the phylum level; some traits discussed below may not be indicative of all taxa within a phylum, especially for the very diverse Proteobacteria, but offer some insight to potential strategies employed.

Consistent with fluorometric and microscopic evaluations, the sequenced relative abundance of cyanobacteria made up an average $18 \pm 9 \%$ of initial abundances and was significantly reduced in two of three experiments. The relative abundance of Actinobacteria, which made up an average $11 \pm 3 \%$ of initial abundances, was likewise reduced in two of three experiments of experiments, demonstrating that strains of bacteria within this phylum are susceptible to $\mathrm{H}_{2} \mathrm{O}_{2}$. In lakes, Actinobacteria are small, thin walled, free-living ultramicrobia $\left(<0.1 \mu \mathrm{m}^{3}\right)$ that are abundant in the epilimnion [34]. Actinobacteria are obligate aerobes [35], and densities decrease with decreasing oxygen levels and depth [34,36]. They are defense specialists that are relatively resistant to grazing, but have slow growth rates compared to other bacteria $[34,37]$. These slow growth rates may make them less likely to recover from initial populations declines induced by $\mathrm{H}_{2} \mathrm{O}_{2}$.

Planctomycetes and Verrucomicrobia, which have a close phylogenetic relationship [38], made up a smaller portion of the total bacterial community $(<5 \%)$ but also appeared susceptible to $\mathrm{H}_{2} \mathrm{O}_{2}$, significantly decreasing in sequenced relative abundance in two of three experiments, and in all experiments, respectively. Verrucomicrobia are usually found throughout the water column and are associated with high-nutrient environments and algal blooms [34]. Prior mesocosm experiments have shown Verrucomicrobia to strongly increase in response to Microcystis degradation [39]. Planctomycetes similarly are capable of breaking down high-molecular weight organic compounds $[40,41]$. Both phyla are also capable of producing bifunctional catalase-peroxidases [42]. Peroxide resistance, benefitting from organic carbon, and declining Microcystis abundances should have all theoretically promoted these groups. The absence of such a response in their sequenced relative abundance may have been a 
function of a larger increase or lesser decline in other bacterial groups or a stronger negative effect of $\mathrm{H}_{2} \mathrm{O}_{2}$ relative to any benefit derived from algal organic matter.

Proteobacteria increased significantly in sequenced relative abundances in one of three experiments. Proteobacteria were one of the most abundant prokaryotes, making up $30 \pm 8 \%$ of initial abundances. Proteobacteria have a relatively short generation time, allowing them to respond rapidly to changing conditions [34] and are copiotrophic, able to assimilate small organic acids as well as degrade complex organic compounds $[34,40,41]$. Proteobacteria also contain catalase-peroxidases and manganese catalases that protect them from oxidative stress [42].

The average initial relative abundance of Bacteroidetes was $27 \pm 4 \%$, and values were significantly higher following $\mathrm{H}_{2} \mathrm{O}_{2}$ exposure in two of three experiments. Bacteroidetes are usually particle associated and chemoorganotrophic [34], and are capable of degrading complex, high-molecular weight organic compounds [34,40,41]. Bacteroidetes become abundant when DOC or algae-derived DOC are high [34], and Bacteroidetes abundances often increase during the degradation of Microcystis blooms [39]. Their ability to benefit from $\mathrm{H}_{2} \mathrm{O}_{2}$ in two experiments and to be unaffected in a third may relate to their exploitation of DOC released by lysing cyanobacteria and/or their association with particles that might scavenge some $\mathrm{H}_{2} \mathrm{O}_{2}$ and thereby protect attached cells.

The findings presented here contrast slightly with Lin et al. (2018) who similarly performed mesocosm experiments and analyzed the $16 \mathrm{~S}$ rDNA for bacterial community shifts in response to $8 \mathrm{mg}$ $\mathrm{H}_{2} \mathrm{O}_{2} \mathrm{~L}^{-1}$. While Firmicutes increased in sequenced relative abundance in that study, Proteobacteria and Bacteroidetes were reduced [32], whereas these two groups increased or were generally unchanged in the present study. Those results, however, emanated from a single experiment that was performed in winter in Dianchi Lake, China, where the temperature was $10^{\circ} \mathrm{C}$ [32]. Moreover, changes in relative abundance can be complex as changes in relative abundance of any one group is also dependent on the response of other groups.

\subsection{Comparison Among Ecosystems}

The reactivity of $\mathrm{H}_{2} \mathrm{O}_{2}$ is influenced by its rate of decay, which can be affected by oxidation-reduction processes and the organic matter content of water bodies $[43,44]$. The nearest measure of organic matter concentration this study performed was algal biomass. Georgica Pond

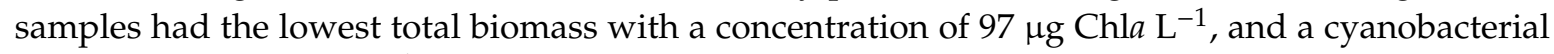
biomass of $73 \mu \mathrm{g} C h l a \mathrm{~L}^{-1}$, which was reduced $99.8 \%$ by $\mathrm{H}_{2} \mathrm{O}_{2}$. Lake Agawam was the next densest,

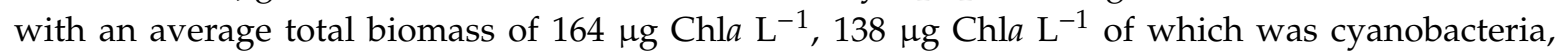

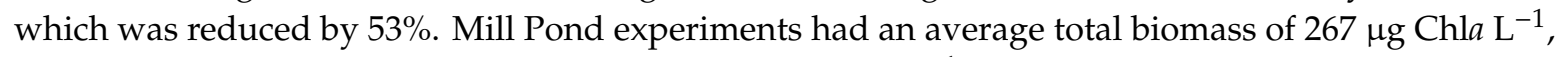

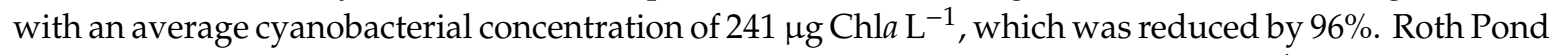

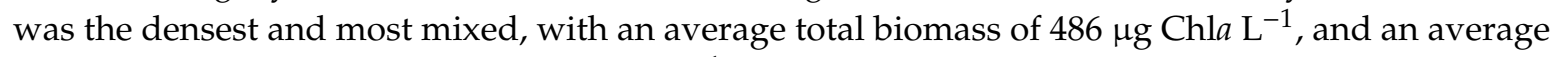
cyanobacterial concentration of $140 \mu \mathrm{g} \mathrm{Chl} a \mathrm{~L}^{-1}$, which was reduced by $67 \%$. Across these four systems, there was no significant relationship between effectiveness of $\mathrm{H}_{2} \mathrm{O}_{2}$ in reduction of cyanobacterial biomass and total biomass (Figure 8a), and, therefore, other factors may have had a greater influence on efficacy. For some individual systems, specifically Lake Agawam and Roth Pond, increasing levels of algal biomass were significantly correlated with decreasing reductions on cyanobacterial biomass during $\mathrm{H}_{2} \mathrm{O}_{2}$ treatments (Lake Agawam, $p<0.005$, Figure 8b; Roth Pond, $p<0.001$, Figure $8 \mathrm{c}$ ), meaning $\mathrm{H}_{2} \mathrm{O}_{2}$ became less effective at controlling cyanobacteria as total algal biomass increased. This trend was not detected in water from Mill Pond or Georgica Pond. Regardless, the findings for Lake Agawam and Roth Pond samples suggest that the efficacy of $\mathrm{H}_{2} \mathrm{O}_{2}$ in controlling cyanobacteria can depending on the levels of total algal biomass, but that the relationship is partly conditional upon other factors that may differ independently across ecosystems including levels of total organic carbon in the water column and the inventory of organic matter within sediments. 

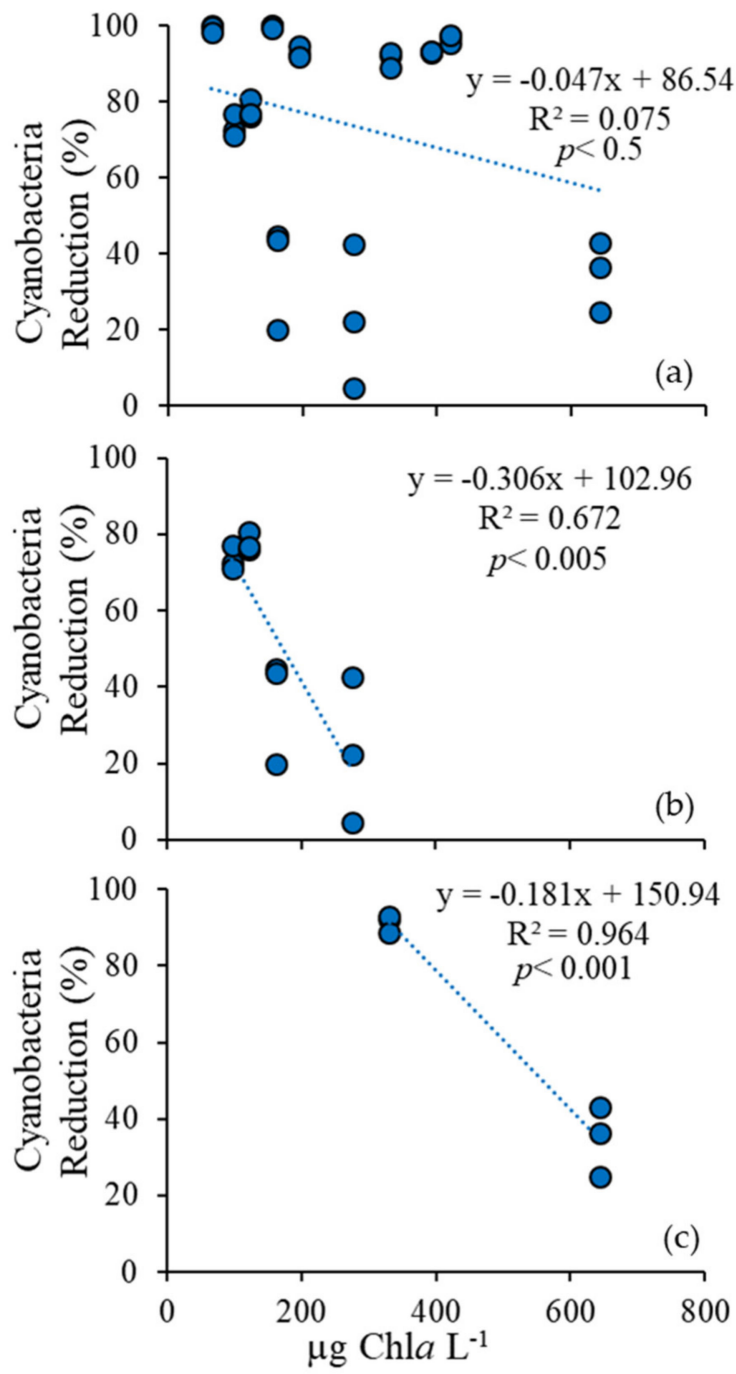

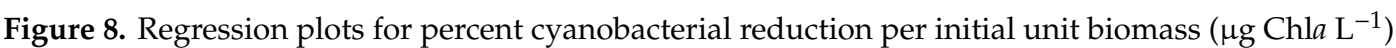
following the addition of $4 \mathrm{mg} \mathrm{L}^{-1} \mathrm{H}_{2} \mathrm{O}_{2}$ for all experiments (a), Lake Agawam experiments (b), and Roth Pond experiments (c).

Across all experiments, initial reductions in cyanobacterial biomass persisted during the four-to-seven-day incubations. Other long-term studies from lakes and wastewater stabilization ponds dominated by Planktothrix found the effects of $\mathrm{H}_{2} \mathrm{O}_{2}$ persisted for five to seven weeks [11,31], and in a mixed assemblage of Microcystis and Planktothrix persisted for three weeks [17]. Longer observations would be required to determine the ability of the cyanobacteria to recover and the time frame within which such a recovery would occur.

\section{Conclusions}

This study demonstrated that $\mathrm{H}_{2} \mathrm{O}_{2}$ administered at a moderate dose $\left(4 \mathrm{mg} \mathrm{L}^{-1}\right)$ consistently inhibits cyanobacteria and promotes the growth of eukaryotic algae, primarily green algae. $\mathrm{H}_{2} \mathrm{O}_{2}$ significantly reduced heterotrophic bacterial densities, with the phylum Actinobacteria most consistently reduced. Other bacterial phyla also declined, but were relatively less impacted, potentially due to their antioxidant enzymes and recovery fueled by use of cyanobacterial-derived organic matter, with some phyla increasing in relative abundance following the addition of $\mathrm{H}_{2} \mathrm{O}_{2} \cdot \mathrm{H}_{2} \mathrm{O}_{2}$ did not successfully reduce cyanobacteria levels below detection or guidance levels in a majority of experiments at the concentrations used here $\left(4 \mathrm{mg} \mathrm{L}^{-1}\right)$. While the elimination of cyanobacteria might have been achieved with higher doses of $\mathrm{H}_{2} \mathrm{O}_{2}$, prior research has suggested that such levels may 
cause collateral damage on non-target organisms [11,12]. The use of bottle experiments here, however, likely maximized contact between $\mathrm{H}_{2} \mathrm{O}_{2}$ and the plankton community, while minimizing scavenging by sediments. Future, larger scale and whole ecosystem experiments may provide deeper insight with regard the true effect and effectiveness of $\mathrm{H}_{2} \mathrm{O}_{2}$ in altering plankton community structure and mitigating cyanobacterial blooms.

\section{Materials and Methods}

Bottle incubation experiments were performed within four study systems: Georgica Pond (latitude, longitude $=40.938671,-72.230216)$, Mill Pond (40.914848, -72.358037), Lake Agawam (40.875074, -72.391942), and Roth Pond (40.911734, -73.123772). Lake Agawam, Mill Pond, and Georgica Pond are shallow (2-3 m) natural freshwater (Lake Agawam, Mill Pond) or brackish (Georgica Pond; salinity 0-20 PSU) water bodies located on Long Island's south shore and are $0.24 \mathrm{~km}^{2}, 0.49 \mathrm{~km}^{2}$, and 1.17 $\mathrm{km}^{2}$, respectively, and known to experience repeated cyanobacterial blooms $[45,46]$. Roth Pond is a man-made, $3 \times 10^{-3} \mathrm{~km}^{2}, 1 \mathrm{~m}$ deep water body on the campus of Stony Brook University, in Stony Brook, NY, USA.

This study presents 11 experiments performed in two rounds (Table 1). The first round of experiments consisted of three experiments from Lake Agawam, three experiments from Mill Pond, one experiment from Roth Pond, and one experiment from Georgica Pond that were evaluated for changes in phytoplankton communities in response to $\mathrm{H}_{2} \mathrm{O}_{2}$ using a bbe Moldaenke (Kiel, Germany) Fluoroprobe. The second round of experiments were performed at Lake Agawam, Mill Pond, and Roth Pond and involved in-depth and detailed investigations of the prokaryotic and eukaryotic plankton communities' responses to $\mathrm{H}_{2} \mathrm{O}_{2}$ using fluorometry, microscopy, flow cytometry, and high-throughput amplicon sequencing.

Table 1. Overview of experiments and analysis performed for each waterbody.

\begin{tabular}{|c|c|c|}
\hline Waterbody & Dates & Analysis \\
\hline Lake Agawam & $\begin{array}{c}7 / 21 / 16 \\
10 / 20 / 16 \\
6 / 9 / 17 \\
10 / 3 / 16\end{array}$ & $\begin{array}{l}\text { Fluorescence only } \\
\qquad \text { Full }^{1}\end{array}$ \\
\hline Mill Pond & $\begin{array}{c}7 / 21 / 16 \\
10 / 20 / 16 \\
6 / 30 / 17 \\
10 / 3 / 16\end{array}$ & $\begin{array}{l}\text { Fluorescence only } \\
\qquad \text { Full }^{1}\end{array}$ \\
\hline Georgica Pond & $7 / 21 / 16$ & Fluorescence only \\
\hline Roth Pond & $\begin{array}{c}6 / 9 / 17 \\
6 / 30 / 17\end{array}$ & $\begin{array}{l}\text { Fluorescence only } \\
\qquad \text { Full }^{1}\end{array}$ \\
\hline
\end{tabular}

${ }^{1}$ Fluorescence, microscopy, flow cytometry, DNA sequencing.

Surface water was collected using 20 L carboys from each site experiencing a cyanobacterial bloom

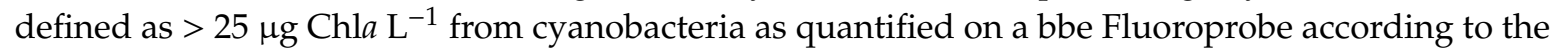
(NYSDEC; details below). Bloom water was transferred from the carboys into 4-L polycarbonate bottles using acid-washed Tygon tubing placed at the bottom of the bottle to reduce bubbling and disturbance of the plankton. Each bottle experiment consisted of two treatments, with three replicate bottles each: an unamended control, and $4 \mathrm{mg} \mathrm{H}_{2} \mathrm{O}_{2} \mathrm{~L}^{-1}$ treatment achieved via the addition of a $3 \% \mathrm{w} / \mathrm{v} \mathrm{H}_{2} \mathrm{O}_{2}$ solution. These $\mathrm{H}_{2} \mathrm{O}_{2}$ levels have been previously shown to reduce levels of Planktothrix but not eukaryotes in a matter of days in European lakes [11,12]. Bottles were incubated for four-to-seven days under ambient light and temperature conditions in an outdoor flow-through table, constantly flushed with water from Old Fort Pond, Southampton, NY, which maintains water temperatures comparable to the shallow lakes and ponds studied here (Figure 9). Initial and final timepoint samples were obtained 
and preserved for microscopy (5\% Lugol's iodine), flow cytometry (10\% buffered formalin stored at $-80^{\circ} \mathrm{C}$ ), and the extraction of DNA (50 mL onto a $0.2 \mu \mathrm{m}, 47 \mathrm{~mm}$ Isopore polycarbonate filter frozen at $-80^{\circ} \mathrm{C}$ ). Lugol's iodine preserved samples were analyzed using a Sedgewick Rafter slide to quantify cyanobacteria at the genus level as well as eukaryotic algae that were broadly categorized as unicellular green algae (chlorophytes) or diatoms. Formalin-preserved samples were used to quantify the abundances of phycocyanin-containing pico-cyanobacteria, pico- and nano-eukaryotic phytoplankton, and SYBR Green I-stained heterotrophic bacteria on a CytoFLEX flow cytometer (Beckman Coulter, Indianapolis, IN, USA) based on fluorescence patterns and particle size [47]. Pico-cyanobacteria are identified here as Cyanobium based on high-throughput sequencing identification results. Fluorescence measurements were made on initial and final live samples on a BBE Fluoroprobe which categorizes algal biomass (Chla) based on the fluorescence signatures of green algae, cyanobacteria, and unicellular brown algae (diatoms, dinoflagellates, raphidophytes) [48]. Whole-water samples (1 mL) were collected and frozen for one experiment for analysis of the cyanobacterial toxin, microcystin, via an Abraxis Microcystins ELISA assay which included lysing cells for a total concentration [49]. Differences between treatments and controls for each parameter measured in the experiments were assessed via a one-way ANOVA. Values below detection were entered as zero.

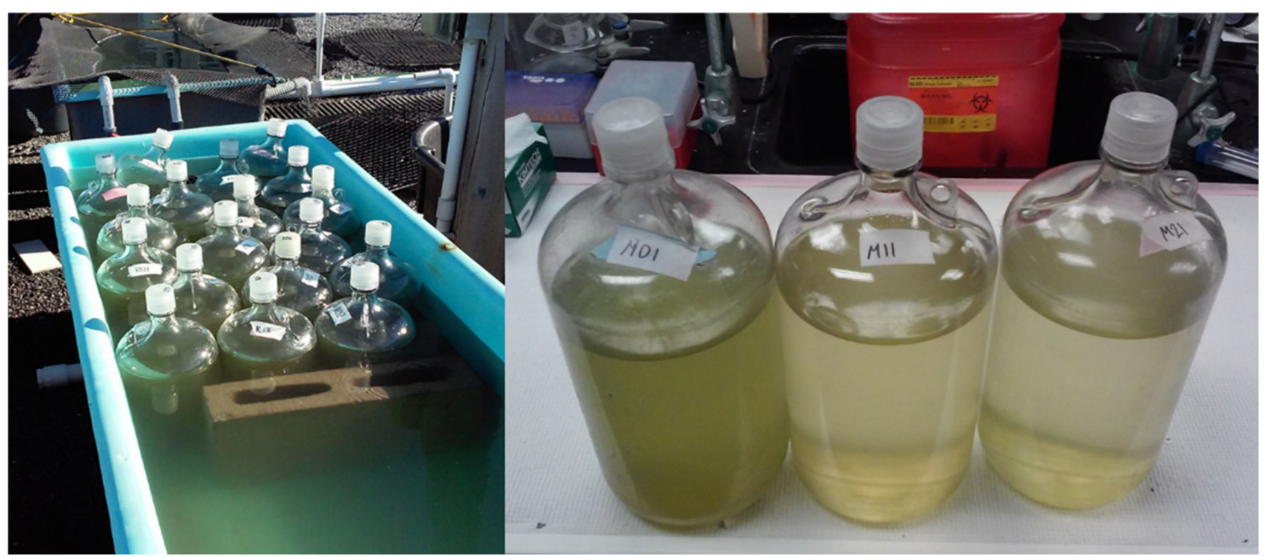

Figure 9. Outdoor flow-through table, and $4 \mathrm{~L}$ bottles used for incubation experiments. Example of pigment change between control and $\mathrm{H}_{2} \mathrm{O}_{2}$ treatments.

\section{DNA Extraction, Sequencing, and Analysis}

DNA barcoding analysis was performed to assess changes in community composition of cyanobacteria and other prokaryotes. Samples were initially heated in a water bath to $65^{\circ}$ for $10 \mathrm{~min}$ to aid in lysing, and extractions were performed using a Qiagen DNeasy ${ }^{\circledR}$ PowerWater $^{\circledR}$ Kit. Double-stranded DNA was quantified on a Qubit ${ }^{\circledR}$ fluorometer using a dsDNA BR Assay kit. Aliquots were normalized to an equal quantity of DNA, and sent to Molecular Research Laboratories (Shallowater, TX, USA) for amplicon sequencing. Paired-end sequencing was performed on an Illumina MiSeq $(2 \times 300 \mathrm{bp})$ following the manufacturer's guidelines. The $16 \mathrm{~S}$ rRNA gene V4 variable region ( 252bp) was amplified using universal primers 515F: 5'-GTG YCA GCM GCC GCG GTAA-3’ [50] and 806RB: 5'-GGA CTA CNV GGG TWT CTA AT-3' [51]. For each sample, an identifying barcode was placed on the forward primer and a 30 cycle PCR using the HotStarTaq Plus Master Mix Kit (Qiagen, Valencia, CA, USA) was performed. The following PCR conditions were used: $94{ }^{\circ} \mathrm{C}$ for 3 min, followed by 28 cycles of $94{ }^{\circ} \mathrm{C}$ for $30 \mathrm{~s}, 53{ }^{\circ} \mathrm{C}$ for $40 \mathrm{~s}$ and $72{ }^{\circ} \mathrm{C}$ for $1 \mathrm{~min}$, and a final elongation step at $72{ }^{\circ} \mathrm{C}$ for $5 \mathrm{~min}$. Samples were purified using calibrated Ampure XP beads and subsequently used to prepare an Illumina DNA library.

Sequence data was processed using the Quantitative Insights into Microbial Ecology QIIME 1 (v1.9.1) and QIIME 2 (v2019.1.0) following the "Moving Pictures" pipeline (QIIME, http://qiime.org; [52]). Raw sequences were depleted of sample barcodes in QIIME 1. Paired-end reads were demultiplexed 
in QIIME 2 using the DEMUX plugin, and were depleted of primers using the Cutadapt Plugin. The library was filtered for chimeric sequences, denoised and dereplicated using the DADA2 plugin. A naïve Bayes classifier was trained using the SILVA rRNA (16S SSU) v132 reference database at 99\% similarity, and was used with the q2-feature-classifier and classify-sklearn plugins to assign taxonomies. The dataset was filtered to remove mitochondria and chloroplast features. Prokaryotic OTUs were examined at the phylum level and were expressed as relative abundance of each. Cyanobacteria OTUs were then examined at the genus level, also expressed as relative abundance. For each set, prokaryote OTUs and cyanobacteria OTUs, relative abundances exceeding 5\% were compared, and the remaining were grouped as "other". Statistical analysis of diversity, as well as shifts in relative abundance were performed in QIIME 2. Absolute abundances of cyanobacterial genera were estimated by multiplying the Fluoroprobe quantified levels of cyanobacterial fluorescence by the relative abundance of each genera exceeding 5\% of the total OTU reads. Raw sequencing data was deposited to the NCBI Sequence Read Archive (SRA) under accession number PRJNA642309.

Author Contributions: Conceptualization, M.W.L. and C.J.G.; Methodology, M.W.L. and C.J.G.; Validation, C.J.G.; Formal analysis, M.W.L. and C.J.G.; Investigation, M.W.L.; Resources, C.J.G.; Data curation, M.W.L.; Writing-Original draft preparation, M.W.L.; Writing-Review and editing, C.J.G.; Visualization, M.W.L.; Supervision, C.J.G; Project administration, C.J.G.; Funding acquisition, C.J.G. All authors have read and agreed to the published version of the manuscript.

Funding: This research was funded by the New York State Department of Environmental Conservation, the Tamarind Foundation, and NOAA's MERHAB program.

Acknowledgments: We acknowledge the support of the New York State Department of Environmental Conservation for support of this project, the New York State Center for Clean Water Technology in making measurements of hydrogen peroxide, and Solitude Lake Management for performing whole lake applications of hydrogen peroxide.

Conflicts of Interest: The authors declare no conflicts of interest.

\section{References}

1. Backer, L.C.; McGillicuddy, D.J., Jr. Harmful algal blooms: At the interface between coastal oceanography and human health. Oceanography 2006, 19, 94. [CrossRef] [PubMed]

2. Bartram, J.; Chorus, I. Toxic Cyanobacteria in Water: A Guide to their Public Health Consequences, Monitoring and Management; CRC Press: London, UK, 1999.

3. United States Environmental Protection Agency. Drinking Water Health Advisory for the Cyanobacterial Microcystin Toxins; United States Environmental Protection Agency: Washington DC, USA, 2015.

4. Bukaveckas, P.A.; Lesutienè, J.; Gasiūnaitè, Z.R.; Ložys, L.; Olenina, I.; Pilkaitytè, R.; Pūtys, Ž.; Tassone, S.; Wood, J. Microcystin in aquatic food webs of the Baltic and Chesapeake Bay regions. Estuar. Coast. Shelf Sci. 2017, 191, 50-59. [CrossRef]

5. Ibelings, B.W.; Chorus, I. Accumulation of cyanobacterial toxins in freshwater "seafood" and its consequences for public health: A review. Environ. Pollut. 2007, 150, 177-192. [CrossRef] [PubMed]

6. Poste, A.E.; Hecky, R.E.; Guildford, S.J. Evaluating microcystin exposure risk through fish consumption. Environ. Sci. Technol. 2011, 45, 5806-5811. [CrossRef]

7. Backer, L.C.; Landsberg, J.H.; Miller, M.; Keel, K.; Taylor, T.K. Canine cyanotoxin poisonings in the United States (1920s-2012): Review of suspected and confirmed cases from three data sources. Toxins 2013, 5 , 1597-1628. [CrossRef]

8. Harke, M.J.; Steffen, M.M.; Gobler, C.J.; Otten, T.G.; Wilhelm, S.W.; Wood, S.A.; Paerl, H.W. A review of the global ecology, genomics, and biogeography of the toxic cyanobacterium, Microcystis spp. Harmful Algae 2016, 54, 4-20. [CrossRef]

9. Paerl, H.W. Nuisance phytoplankton blooms in coastal, estuarine, and inland waters 1. Limnol. Oceanogr. 1988, 33, 823-843. [CrossRef]

10. Barrington, D.J.; Ghadouani, A.; Ivey, G.N. Environmental factors and the application of hydrogen peroxide for the removal of toxic cyanobacteria from waste stabilization ponds. J. Environ. Eng. 2011, 137, 952-960. [CrossRef] 
11. Matthijs, H.C.; Visser, P.M.; Reeze, B.; Meeuse, J.; Slot, P.C.; Wijn, G.; Talens, R.; Huisman, J. Selective suppression of harmful cyanobacteria in an entire lake with hydrogen peroxide. Water Res. 2012, 46, 1460-1472. [CrossRef]

12. Matthijs, H.C.; Jančula, D.; Visser, P.M.; Maršálek, B. Existing and emerging cyanocidal compounds: New perspectives for cyanobacterial bloom mitigation. Aquat. Ecol. 2016, 50, 443-460. [CrossRef]

13. Drábková, M.; Admiraal, W.; Maršálek, B. Combined exposure to hydrogen peroxide and light selective effects on cyanobacteria, green algae, and diatoms. Environ. Sci. Technol. 2007, 41, 309-314. [CrossRef] [PubMed]

14. Barrington, D.J.; Ghadouani, A. Application of hydrogen peroxide for the removal of toxic cyanobacteria and other phytoplankton from wastewater. Environ. Sci. Technol. 2008, 42, 8916-8921. [CrossRef] [PubMed]

15. Samuilov, V.; Timofeev, K.; Sinitsyn, S.; Bezryadnov, D. $\mathrm{H}_{2} \mathrm{O}_{2}$-induced inhibition of photosynthetic $\mathrm{O}_{2}$ evolution by Anabaena variabilis cells. Biochemistry 2004, 69, 926-933.

16. Drabkova, M.; Maršálek, B.; Admiraal, W. Photodynamic therapy against cyanobacteria. Environ. Toxicol. Int. J. 2007, 22, 112-115. [CrossRef] [PubMed]

17. Barrington, D.J.; Reichwaldt, E.S.; Ghadouani, A. The use of hydrogen peroxide to remove cyanobacteria and microcystins from waste stabilization ponds and hypereutrophic systems. Ecol. Eng. 2013, 50, 86-94. [CrossRef]

18. Zilliges, Y.; Kehr, J.-C.; Meissner, S.; Ishida, K.; Mikkat, S.; Hagemann, M.; Kaplan, A.; Borner, T.; Dittmann, E. The Cyanobacterial Hepatotoxin Microcystin Binds to Proteins and Increases the Fitness of Microcystis under Oxidative Stress Conditions. PLoS ONE 2011, 6, e17615. [CrossRef]

19. Schuurmans, J.M.; Brinkmann, B.W.; Makower, A.K.; Dittmann, E.; Huisman, J.; Matthijs, H.C. Microcystin interferes with defense against high oxidative stress in harmful cyanobacteria. Harmful Algae 2018, 78, 47-55. [CrossRef]

20. Passardi, F.; Zamocky, M.; Favet, J.; Jakopitsch, C.; Penel, C.; Obinger, C.; Dunand, C. Phylogenetic distribution of catalase-peroxidases: Are there patches of order in chaos? Gene 2007, 397, 101-113. [CrossRef]

21. Bernroitner, M.; Zamocky, M.; Furtmüller, P.G.; Peschek, G.A.; Obinger, C. Occurrence, phylogeny, structure, and function of catalases and peroxidases in cyanobacteria. J. Exp. Bot. 2009, 60, 423-440. [CrossRef]

22. Barroin, G.; Feuillade, M. Hydrogen peroxide as a potential algicide for Oscillatoria rubescens DC. Water Res. 1986, 20, 619-623. [CrossRef]

23. Lürling, M.; Meng, D.; Faassen, E.J. Effects of hydrogen peroxide and ultrasound on biomass reduction and toxin release in the cyanobacterium, Microcystis aeruginosa. Toxins 2014, 6, 3260-3280. [CrossRef] [PubMed]

24. Gao, L.; Pan, X.; Zhang, D.; Mu, S.; Lee, D.-J.; Halik, U. Extracellular polymeric substances buffer against the biocidal effect of $\mathrm{H} 2 \mathrm{O} 2$ on the bloom-forming cyanobacterium Microcystis aeruginosa. Water Res. 2015, 69, 51-58. [CrossRef] [PubMed]

25. Schrader, K.K.; Dayan, F.E. Antioxidant enzyme activities in the cyanobacteria Planktothrix agardhii, Planktothrix perornata, Raphidiopsis brookii, and the green alga Selenastrum capricornutum. In Handbook on Cyanobacteria: Biochemistry, Biotechnology, and Applications; Nova Science Publishers: Hauppauge, NY, USA, 2010; pp. 473-483.

26. Moore, D.; O’Donohue, M.; Garnett, C.; Critchley, C.; Shaw, G. Factors affecting akinete differentiation in Cylindrospermopsis raciborskii (Nostocales, Cyanobacteria). Freshw. Biol. 2005, 50, 345-352. [CrossRef]

27. Moustaka-Gouni, M.; Kormas, K.A.; Vardaka, E.; Katsiapi, M.; Gkelis, S. Raphidiopsis mediterranea Skuja represents non-heterocytous life-cycle stages of Cylindrospermopsis raciborskii (Woloszynska) Seenayya et Subba Raju in Lake Kastoria (Greece), its type locality: Evidence by morphological and phylogenetic analysis. Harmful Algae 2009, 8, 864-872. [CrossRef]

28. Nielsen, K.M.; Johnsen, P.J.; Bensasson, D.; Daffonchio, D. Release and persistence of extracellular DNA in the environment. Environ. Biosaf. Res. 2007, 6, 37-53. [CrossRef]

29. Zulkefli, N.; Kim, K.-H.; Hwang, S.-J. Effects of Microbial Activity and Environmental Parameters on the Degradation of Extracellular Environmental DNA from a Eutrophic Lake. Int. J. Environ. Res. Public Health 2019, 16, 3339. [CrossRef]

30. Yang, Z.; Buley, R.P.; Fernandez-Figueroa, E.G.; Barros, M.U.G.; Rajendran, S.; Wilson, A.E. Hydrogen peroxide treatment promotes chlorophytes over toxic cyanobacteria in a hyper-eutrophic aquaculture pond. Environ. Pollut. 2018, 240, 590-598. [CrossRef] 
31. Sinha, A.K.; Eggleton, M.A.; Lochmann, R.T. An environmentally friendly approach for mitigating cyanobacterial bloom and their toxins in hypereutrophic ponds: Potentiality of a newly developed granular hydrogen peroxide-based compound. Sci. Total Environ. 2018, 637, 524-537. [CrossRef]

32. Lin, L.; Shan, K.; Xiong, Q.; Zhou, Q.; Li, L.; Gan, N.; Song, L. The ecological risks of hydrogen peroxide as a cyanocide: Its effect on the community structure of bacterioplankton. J. Oceanol. Limnol. 2018, 36, 2231-2242. [CrossRef]

33. Smayda, T.J.; Reynolds, C.S. Strategies of marine dinoflagellate survival and some rules of assembly. J. Sea Res. 2003, 49, 95-106. [CrossRef]

34. Newton, R.J.; Jones, S.E.; Eiler, A.; McMahon, K.D.; Bertilsson, S. A guide to the natural history of freshwater lake bacteria. Microbiol. Mol. Biol. Rev. 2011, 75, 14-49. [CrossRef] [PubMed]

35. Den Hengst, C.D.; Buttner, M.J. Redox control in actinobacteria. Biochim. Biophys. Acta (BBA)-Gen. Subj. 2008, 1780, 1201-1216. [CrossRef] [PubMed]

36. Taipale, S.; Jones, R.I.; Tiirola, M. Vertical diversity of bacteria in an oxygen-stratified humic lake, evaluated using DNA and phospholipid analyses. Aquat. Microb. Ecol. 2009, 55, 1-16. [CrossRef]

37. Šimek, K.; Horňák, K.; Jezbera, J.; Nedoma, J.; Vrba, J.; Straškrábová, V.; Macek, M.; Dolan, J.R.; Hahn, M.W. Maximum growth rates and possible life strategies of different bacterioplankton groups in relation to phosphorus availability in a freshwater reservoir. Environ. Microbiol. 2006, 8, 1613-1624. [CrossRef]

38. Wagner, M.; Horn, M. The Planctomycetes, Verrucomicrobia, Chlamydiae and sister phyla comprise a superphylum with biotechnological and medical relevance. Curr. Opin. Biotechnol. 2006, 17, 241-249. [CrossRef]

39. Shao, K.; Gao, G.; Chi, K.; Qin, B.; Tang, X.; Yao, X.; Dai, J. Decomposition of Microcystis blooms: Implications for the structure of the sediment bacterial community, as assessed by a mesocosm experiment in Lake Taihu, China. J. Basic Microbiol. 2013, 53, 549-554. [CrossRef]

40. Nold, S.C.; Zwart, G. Patterns and governing forces in aquatic microbial communities. Aquat. Ecol. 1998, 32, 17-35. [CrossRef]

41. DeLong, E.F.; Franks, D.G.; Alldredge, A.L. Phylogenetic diversity of aggregate-attached vs. free-living marine bacterial assemblages. Limnol. Oceanogr. 1993, 38, 924-934. [CrossRef]

42. Zámocký, M.; Gasselhuber, B.; Furtmüller, P.G.; Obinger, C. Molecular evolution of hydrogen peroxide degrading enzymes. Arch. Biochem. Biophys. 2012, 525, 131-144. [CrossRef]

43. Cooper, W.J.; Zepp, R.G. Hydrogen peroxide decay in waters with suspended soils: Evidence for biologically mediated processes. Can. J. Fish. Aquat. Sci. 1990, 47, 888-893. [CrossRef]

44. Häkkinen, P.J.; Anesio, A.M.; Granéli, W. Hydrogen peroxide distribution, production, and decay in boreal lakes. Can. J. Fish. Aquat. Sci. 2004, 61, 1520-1527. [CrossRef]

45. Gobler, C.J.; Davis, T.W.; Coyne, K.J.; Boyer, G.L. Interactive influences of nutrient loading, zooplankton grazing, and microcystin synthetase gene expression on cyanobacterial bloom dynamics in a eutrophic New York lake. Harmful Algae 2007, 6, 119-133. [CrossRef]

46. Davis, T.W.; Berry, D.L.; Boyer, G.L.; Gobler, C.J. The effects of temperature and nutrients on the growth and dynamics of toxic and non-toxic strains of Microcystis during cyanobacteria blooms. Harmful Algae 2009, 8 , 715-725. [CrossRef]

47. Kang, Y.; Koch, F.; Gobler, C.J. The interactive roles of nutrient loading and zooplankton grazing in facilitating the expansion of harmful algal blooms caused by the pelagophyte, Aureoumbra lagunensis, to the Indian River Lagoon, FL, USA. Harmful Algae 2015, 49, 162-173. [CrossRef]

48. Jankowiak, J.; Hattenrath-Lehmann, T.; Kramer, B.J.; Ladds, M.; Gobler, C.J. Deciphering the effects of nitrogen, phosphorus, and temperature on cyanobacterial bloom intensification, diversity, and toxicity in western Lake Erie. Limnol. Oceanogr. 2019, 64, 1347-1370. [CrossRef]

49. Harke, M.J.; Gobler, C.J. Daily transcriptome changes reveal the role of nitrogen in controlling microcystin synthesis and nutrient transport in the toxic cyanobacterium, Microcystis aeruginosa. BMC Genom. 2015, 16, 1068. [CrossRef] [PubMed]

50. Parada, A.E.; Needham, D.M.; Fuhrman, J.A. Every base matters: Assessing small subunit rRNA primers for marine microbiomes with mock communities, time series and global field samples. Environ. Microbiol. 2016, 18, 1403-1414. [CrossRef] [PubMed] 
51. Klindworth, A.; Pruesse, E.; Schweer, T.; Peplies, J.; Quast, C.; Horn, M.; Glöckner, F.O. Evaluation of general $16 \mathrm{~S}$ ribosomal RNA gene PCR primers for classical and next-generation sequencing-based diversity studies. Nucleic Acids Res. 2012, 41, e1. [CrossRef]

52. Caporaso, J.G.; Kuczynski, J.; Stombaugh, J.; Bittinger, K.; Bushman, F.D.; Costello, E.K.; Fierer, N.; Peña, A.G.; Goodrich, J.K.; Gordon, J.I.; et al. QIIME allows analysis of high-throughput community sequencing data. Nat. Methods 2010, 7, 335-336. [CrossRef] [PubMed]

C 2020 by the authors. Licensee MDPI, Basel, Switzerland. This article is an open access article distributed under the terms and conditions of the Creative Commons Attribution (CC BY) license (http://creativecommons.org/licenses/by/4.0/). 